\title{
Article \\ A Climate Alliance through Transfer: Transfer Design in an Economic Conflict Model
}

\author{
Marcel Franke 1,2,*(D) and Bernhard K. J. Neumärker 1,2 (D) \\ 1 Götz Werner Chair of Department of Economic Policy and Constitutional Economic Theory, \\ University of Freiburg, 79098 Freiburg, Germany; bernhard.neumaerker@vwl.uni-freiburg.de \\ 2 Freiburg Institute for Basic Income Studies (FRIBIS), University of Freiburg, 79098 Freiburg, Germany \\ * Correspondence: marcel.franke@vwl.uni-freiburg.de
}

Citation: Franke, M.; Neumärker, B.K.J. A Climate Alliance through Transfer: Transfer Design in an Economic Conflict Model. World 2022,

3, 112-125. https://doi.org/

$10.3390 /$ world 3010006

Academic Editors: Manfred

Max Bergman, Jungho Baek and

Mario D'Amico

Received: 30 December 2021

Accepted: 14 February 2022

Published: 17 February 2022

Publisher's Note: MDPI stays neutral with regard to jurisdictional claims in published maps and institutional affiliations.

Copyright: (c) 2022 by the authors. Licensee MDPI, Basel, Switzerland. This article is an open access article distributed under the terms and conditions of the Creative Commons Attribution (CC BY) license (https:// creativecommons.org/licenses/by/ $4.0 /)$.

\begin{abstract}
For decades, combating climate change has been a global challenge, which requires jointly coordinated efforts by numerous, international actors. However, it has been shown time and again that agreeing on globally binding agreements without a global government proves difficult. To this end, this paper examines the possibility of a tolerance premium. This means a transfer payment in exchange for accepting and complying with the associated agreement. The provider of this tolerance premium determines the conditions of its payment to set desired incentives. Thus, collective decision making can also be self-enforced without a higher authority. This scenario is studied analytically based on Dixit's conflict model. The study shows that the optimal tolerance premium depends only on the value of the prize to the transferee and that this can result in a stalling of the conflict. The implications of this model shed light on the design of global climate agreements that are self-enforcing without the need for a global government. For this purpose, the upfront payment of funds and their reimbursement as a tolerance premium serve as an incentive to comply with collectively agreed rules in climate policy.
\end{abstract}

Keywords: global climate agreement; conflict model; peace; contest success function; transfer; global government

\section{Introduction}

Climate change does not stop at national borders. This characteristic makes the preservation of a livable climate a public good on an international scale [1]. The usual economic answer to the question of how to manage a public good is provision by the state. It is characterized by the fact that the project can be planned and implemented at a higher organizational level that is binding through regulation. Individual contracts and voluntary private agreements are doomed to fail or to create an undersupply of the public good, since there is always an incentive to avoid excessive participation in the cost of the common project. This behavior is known as free riding [2]. However, at the international level, there is no global government that could take over the provision of public goods [3].

A lack of effort to implement the goals is common, after an agreement for climate protection has been reached [4-6]. Efforts for a global government for the purpose of climate protection [7-10] have so far been unable to solve the problem. The two-level issue between governments on the international level and between government and citizenry on the national level [11] increases the coordination problem. According to Blankart (2017), the climate problem cannot be solved by treating it as an international public good. The hope lies in national implementation [12] (pp. 412-413).

This hopeless situation can be understood as a conflict over the cost of providing climate protection. Thus, this article presents the conflict model according to Dixit (1987) [13], in which two nations initially divide a prize by means of investment in conflict activities, which will be explained below. Provided that mitigation of climate change is set as one of the most important goals of our time, it is only a question of who pays the costs of 
implementing the required measures [14,15]. Therefore, savings of necessary effort in this matter can be understood as the contested prize in the conflict model. Conflict activities can be any costly actions detrimental to the goal. Behaviors such as not adhering to agreed goals [16], allowing, concealing, and supporting environmentally damaging projects [17,18], and negotiating special conditions in participation or special funding benefits make implementing climate agreements difficult [19]. Examples are the protectionism of industries that are harmful to the climate, such as the continued use of coal energy, and the refusal to contribute an adequate share to climate protection. Important terms are:

- $\quad$ Prize in the conflict model: savings of necessary effort in achieving the shared goal.

- Conflict activities: any actions, usually costly, which are detrimental to the shared goal.

- Conflict investments: the monetary representation of the conflict activities.

- Winning probability: share of the prize the player gets.

Departing from this situation, this paper examines how one conflict participant can incentivize the others to behave as desired by offering them a payment. The design of this payment is a core problem of principal-agent theory [20]. In the model, the transfer provider thereby appropriates the entire gain in an efficient manner. For the design of a climate agreement, this means that the transfer provider takes responsibility for climate protection as a joint enterprise and thus manages possible profits through savings and implementation processes with less conflict. This implementation requires appropriate equipment and freedom for the transfer designer. This leads to the hypothesis that a transfer payment can end wasteful rent-seeking. Thus, an appropriate transfer design can yield efficiency gains in the implementation of climate targets, assuming that the distribution of the costs for the provision of climate protection can be interpreted as a rent-seeking model. This approach sheds light on the distribution from the point of view of conflict economics.

The model used is a basic rent-seeking contest model [21]. Its general nature allows the application in numerous fields, for example politics, war, and peace [22,23]. The competition between the players makes cooperation unlikely, especially due to the zero-sum nature of the game. Therefore, the approach falls into the realm of non-cooperative game theory [24] and joins game-theoretic studies of climate negotiations [25-28]. Further, there are plenty of approaches that solve the core problem of a prisoner's dilemma and provision of public goods by voluntary contributions $[29,30]$. Nevertheless, these approaches may have difficulty solving the problem of underprovision sufficiently. On the other hand, top-down approaches are not applicable in international bargaining, and the theory of international bargaining is not too optimistic about solving the problem [31,32]. In addition, finding a stable coalition to tackle the problem together seems difficult [33]. In a similar vein, transfers are expected to fail [34]. Bagwell investigated an exit clause in stabilizing the WTO, which also includes the possibility for transfer [35], and Kappius and Neumärker investigated whether an exit clause makes the European Union self-enforcing [36]. These approaches are useful if the efficiency gain generated by an alliance can be considered optional. Facing the consequences of climate warming, this may fall short in being effective [37].

This paper suggests settling the conflict over the distribution of costs via a transfer offered by one player. This solution contains a principal-agent problem, where the principal wants to incentivize a desired behavior in the agent $[38,39]$. The design of such a transfer program may be based in detail on the literature about payment for ecosystem services. Based on the principal-agent problem, this literature investigates efficient incentivization while considering the information asymmetry the regulator faces $[40,41]$. Therefore, it complements research on Pareto-relevant redistribution due to, for example, philanthropy [42], insurance and security [43], malice and envy [44], or imperfect capital markets [45] (p. 256) on the societal level [46]. The transfer follows the concept of the "tolerance premium" [47]. By paying competitors in exchange for their compliance, costly conflict investments can be saved [48,49] (pp. 73-77). There is also a discussion on the Carbon Tax-financed "Climate 
Bonus" as one such peace-, tolerance- and solidarity-enforcing device [50]. Therefore, it may be useful buying out others from their conflict calculus.

The paper proceeds as follows: Section 2 presents the basic conflict model and its solution to the posterior subgame, Section 3 discusses the possibilities of determining an optimal transfer offer, Section 4 describes the changes compared to a situation with multiple participants, and Section 5 discusses the model and the implications for climate agreements and draws conclusions.

\section{The Conflict Model}

This section briefly introduces the conflict model by Dixit [13] (pp. 892-897) according to the notation by Wärneryd [51]. Additionally, the possibility of pacification through transfers was considered by Cuesta and Murshed [52] in the context of civil war. Two-level problems of the "harmonization" of international and national strategies [11] are ignored. A legend of the variables can be found at the end of the article. The model envisages the maximization of the objective function $u_{i}$ by participating in a competition for a prize, $v$. The two PLAYERS $i \in\{1,2\}$ invest in conflict activities to increase their share of the prize. The conflict investment incurs costs in this process.

The contest success function (CSF) gives the probability of winning $p_{i}$ of the respective competitor depending on the conflict efforts $x_{i}$ of both. The ratio CSF examined here is

$$
p_{i}\left(x_{1}, x_{2}\right)= \begin{cases}x_{i} /\left(x_{1}+x_{2}\right) & \text { for }\left(x_{1}+x_{2}\right)>0 \\ 1 / 2 & \text { else. }\end{cases}
$$

The design of the CSF represents an empirical estimation task for the use case. Two common variants have emerged from the theoretical literature that are suitable for different situations [53]: the ratio and the difference function, whereby a peaceful settlement is less likely for the former type, which is why the latter yields stronger results for pacification through transfers [54]. Conflict success can be interpreted here as a share of the coveted object on the one hand or as the probability of winning the entire prize on the other [13] (p. 896). For risk-neutral PLAYERS, both interpretations are equivalent in terms of the expected value.

The PLAYER's objective functions are

$$
u_{i}\left(x_{1}, x_{2}\right)=p_{i}\left(x_{1}, x_{2}\right) v_{i}-x_{i} .
$$

$v_{i}$ is $i$ 's valuation of the total prize upon receipt of it. The costs of the conflict investments $x_{i}$ enter the calculation with a normalized prize. Budget and liquidity problems are not considered.

It is assumed a public good needs to be provided. This leads to a prisoner's dilemma situation. In the classical prisoner's dilemma, the public good is underprovided or the provision fails, due to incentives to free ride. The gain in the model is a fixed prize. This can be accomplished by avoiding participating in bearing the costs of provision of the public good while other contributors overtake the provision. Since the provision is carried out, someone must bear the costs. Thus, only a fixed amount of buffer, which corresponds to the prize in the model, can be bargained over without endangering the provision of the public good. The winning probability in the model can be understood as the share of this buffer that PLAYER 1 is able to win for themselves.

The simultaneous optimization of the objective function [51] (p. 3) results in the reaction functions

$$
x_{i}^{R}\left(x_{j}\right)=\sqrt{x_{j} v_{i}}-x_{j} .
$$


The superscript index $R$ indicates the reaction function. The Cournot equilibrium conflict investments marked by the superscript index $c$ are as follows

$$
x_{i}^{c}=\frac{v_{i}^{2} v_{j}}{\left(v_{1}+v_{2}\right)^{2}} .
$$

The index $j$ stands for the respective competitor. The payout of the competitors in this game is

$$
u_{i}^{c}=\frac{v_{i}^{3}}{\left(v_{1}+v_{2}\right)^{2}} \text {. }
$$

\section{Design of the Transfer System}

In the following, first a situation of two PLAYERS is considered in which PLAYER 1 can make a binding, and thus credible, transfer announcement to PLAYER 2. The situation is represented as:

- $\quad$ STAGE 1: PLAYER 1 announces and pre-commits to the transfer program depending on the conflict investment.

- $\quad$ STAGE 2: Both PLAYER 1 and 2 simultaneously commit to conflict investments.

- STAGE 3: Conflict results are distributed. Settlement of the transfer depending on the commitment in STAGE 1 takes place, considering conflict investment in STAGE 2.

PLAYER 1 considers, at STAGE 1 , to design a comprehensive transfer $t\left(x_{2}\right)$, which is only paid if PLAYER 2 refrains from conflict activities altogether, i.e., it chooses $x_{2}^{t}=0$, where $t$ may be used as superscript index to indicate conflict investments in accordance with the transfer incentives. PLAYER 1 anticipates the sub-game of STAGE 2 while planning the binding tender of a premium for low conflict investment. For simplicity, the transfer t sometimes equals one simple value instead of the two conditional cases. In this case, only the first line, the case of the transfer being accepted, has to be applied. The transfer program to be considered is

$$
t\left(x_{2}\right)= \begin{cases}u_{2}\left(x_{1}, x_{2}^{o}\right) & \text { for } x_{2}=0 \\ 0 & \text { else. }\end{cases}
$$

$x_{2}^{o}$ represents the conflict investment of PLAYER 2 if the transfer is rejected, marked by the superscript index $o$. This transfer transforms the other PLAYER's decision into a trivial choice of identical payoffs, since the corresponding objective function is

$$
u_{2}\left(x_{1}, x_{2}, t\right)=\left\{\begin{array}{l}
u_{2}\left(x_{1}, x_{2}^{o}\right) \text { for } x_{2}=0 \\
u_{2}\left(x_{1}, x_{2}\right) \text { for } x_{2}>0
\end{array}\right.
$$

where $x_{2}=x_{2}^{o}$ for $x_{2}>0$ is chosen according to $x_{2}^{R}$, since $u_{i}\left(x_{1}, x_{2}\right)$ finds its maximum value there as a function of $x_{1}$. Thus, $x_{2}=0$ is a weakly dominant strategy. In this article, for the sake of simplicity, a lower-ranking lexicographic preference for a peaceful settlement is assumed. Alternatively, a marginal increase in the transfer could tip the scales. Thus, in the following it is assumed that PLAYER 2 sticks anticipatorily to their weakly dominant strategy in $x_{2}=0$ and always prefers to accept an offer of $t\left(x_{2}\right)$ to the equivalent conflict outcome.

The transfer must be considered in STAGE 2 to lead to a change in behavior on the part of the potential transferee. Therefore, the transfer must be credibly processed in accordance with the declaration in STAGE 1 [55]. Otherwise, it is always cheaper for the transfer payer to pay out nothing in STAGE 3 (an option that the assumed homo economicus always chooses). Anticipating this, the recipient ignores any prospects of a transfer in STAGE 2, and there is no behavioral adjustment anyway [56]. However, if PLAYER 1 can establish a binding rule in STAGE 1 that is mandatorily followed in STAGE 3, PLAYER 2 has reason 
to react to the payoff structure of the transfer. The ability to credibly announce transfers by those in need of protection could be established in repeated games with an uncertain time horizon and thus fulfil the criterion of self-enforcing cooperation [57]. Choosing conflict is then the exit option of the recipient from the transfer program which defines the self-enforcing character and level of the transfer [36].

A possible example is the plan of the European Union (EU) to reduce carbon emissions by $30 \%$ outside of the EU emission trading system of their 2005 levels by 2030 [58]. Therefore, a plan to distribute the burden of reducing the emissions is required. This can lead to the situation presented in two ways. First, when bargaining for an agreement, the parties can invest in arguments to lower their contribution. For example, economically weaker countries may argue they have no sufficient capabilities or should be allowed to catch up on historical pollution, while economically stronger countries may argue everyone should contribute the same. Secondly, as soon as the agreement must be implemented, the incentives to avoid the costs do not fade. They may take the form of fraud, accepting contractual penalties or even renegotiation, as the withdrawal of the United States from the Paris Agreement under President Trump demonstrated.

In contrast to the classical prisoner's dilemma game, PLAYER 1 is aware of the problem of free riding. Thus, it announces incentives to PLAYER 2 to encourage them not invest in conflict and to cooperate in providing the public good of climate protection by bringing the required effort and payment in STAGE 1 . This way, the problems after the negotiation took place can be eased by the design of a fitting transfer program. Even the problems during the bargaining over a climate agreement can be separated into "how to achieve the goal" and "who pays for it" via the transfer program. The PLAYER offering a successful transfer acquires the entire prize, i.e., the available buffer, and is able to distribute and use it according to her own desires and to sustain the transfer plan. Thus, this PLAYER is incentivized to solve the first parts efficiently. The latter problem may be solved by the conflict equilibrium, as the remainder of this article investigates. Therefore, such a transfer must be worthwhile for PLAYER 1. Her objective function is then

$$
u_{1}\left(x_{1}, x_{2}\right)= \begin{cases}v_{1}-x_{1}^{R}\left(x_{2}^{o}\right)-t\left(x_{2}^{o}\right) & \text { for } x_{2}=0 \\ u_{1}\left(x_{1}^{R}\left(x_{2}^{o}\right), x_{2}^{o}\right) & \text { for } x_{2}>0\end{cases}
$$

Substitution of $t\left(x_{2}\right)$ and $x_{1}=x_{1}^{R}\left(x_{2}^{o}\right)$ yields

$$
u_{1}\left(x_{1}^{R}\left(x_{2}^{o}\right), x_{2}\right)= \begin{cases}v_{1}-x_{1}^{R}\left(x_{2}^{o}\right)-u_{2}\left(x_{1}^{R}\left(x_{2}^{o}\right), x_{2}^{o}\right) & \text { for } x_{2}=0 \\ u_{1}\left(x_{1}^{R}\left(x_{2}^{o}\right), x_{2}^{o}\right) & \text { for } x_{2}>0 .\end{cases}
$$

The property of the Cournot equilibrium as a solution of simultaneous decisions at the intersection of the reaction functions poses a challenge for the design of a corresponding transfer. The use of optimal conflict investments $x_{1}^{R}\left(x_{2}\right)$ depends for both actors on the decision of the other PLAYER. Anticipation in STAGE 1 of $x_{2}^{o}$ is significant for setting $u_{2}\left(x_{1}, x_{2}^{o}\right)$ to determine the optimal transfer amount.

Moreover, in STAGE 2, the offer of transfer from PLAYER 1 is already on the table and could be used to transport information about $x_{1}$. This leads to the discussion about the expectations of conflict investment of one to the expectations of the other and so on. Consider the following cases: a. Holding the Cournot equilibrium $x_{1}=x_{1}^{c}$ and expecting it. b. $x_{1} \rightarrow 0$ and expectation of it. Finally, c. $x_{1}$ is chosen so that the marginal benefits of increasing the transfer and those of increasing $x_{1}$ are equal at the same marginal cost, so the best option is always exhausted, which is expected by the PLAYERS. 
Each of the cases is interesting from an analytical point of view, as the design of transfers shows different agreement gains depending on the bargaining situation, here depending on expectations and threat points. From an application-oriented point of view, the implications of different expectations are interesting. In this regard, a. resembles a possible morning-after effect, without adjustment of expectations in the conflict investments. In real-world considerations, the adjustment of expectations needs time, meaning that relatively high conflict investments need to be expected at the introduction of a transfer system. The scenario of a peaceful idyll is investigated in b., and it is shown that this scenario is not optimal. Instead, scenario c. presents the new equilibrium to be expected in the long term.

It should also be noted that these cases differ from the situation of an always truthful expectation. For then PLAYER 1 would determine $x_{1}$ quasi sequentially before PLAYER 2 . This situation would correspond to a Stackelberg model in STAGE 2 [59] (pp. 218-220). The investigation of this setting in a Stackelberg model would be interesting for further research. Similarly, an investigation of disappointed expectations in connection with the optimal transfer design could follow.

\section{a. Adherence to the Cournot equilibrium}

From the status quo of a game consisting of an isolated STAGE 2, the expectation $x_{1}=x_{1}^{c}$ could set in for PLAYER 2 or persist until proven wrong. On the other hand, PLAYER 1 may also show a tendency to traditionally hold on to a clear reference point despite the new situation of a transfer possibility. Likewise, this case serves as an analytical reference point. Thus, no changes occur here, except for the introduction of the transfer.

For the Cournot equilibrium, the conflict investments for PLAYER 2 are $x_{2}^{o}=x_{2}^{R}=x_{2}^{c}$, and the objective function $u_{i}^{c}$ results. Insertion in (9) yields

$$
u_{1}= \begin{cases}v_{1}-x_{1}^{c}-u_{2}^{c} & \text { for } x_{2}=0 \\ u_{1}^{c} & \text { for } x_{2}>0\end{cases}
$$

Substituting $x_{1}^{c}$ and $u_{2}^{c}$ gives the "indirect" objective function

$$
u_{1}= \begin{cases}v_{1}-\frac{v_{1}^{2} v_{2}}{\left(v_{1}+v_{2}\right)^{2}}-\frac{v_{2}^{3}}{\left(v_{1}+v_{2}\right)^{2}} & \text { for } x_{2}=0 \\ \frac{v_{1}^{3}}{\left(v_{1}+v_{2}\right)^{2}} & \text { for } x_{2}>0 .\end{cases}
$$

The consideration of the situation, with respect to the accepted transfer and the conflict equilibrium, is as follows

$$
v_{1}-\frac{v_{1}^{2} v_{2}}{\left(v_{1}+v_{2}\right)^{2}}-\frac{v_{2}^{3}}{\left(v_{1}+v_{2}\right)^{2}}=\frac{v_{1}^{3}}{\left(v_{1}+v_{2}\right)^{2}} .
$$

If the left side is larger (smaller) than the right side, the transfer is (not) worthwhile for PLAYER 1. Equation (12) determines the situation in which PLAYER 1 is indifferent about providing a transfer or not, and yields the ratio that marks the break-even point at

$$
v_{2}=0.5\left(v_{1}+\sqrt{5} v_{1}\right) \approx 1.618 v_{1}
$$

The following three numerical examples (numerical examples are rounded to whole numbers) illustrate the result:

(a) $\quad v_{1}=1000 ; v_{2}=1600$. The ratio is slightly higher than for indifference, so a transfer is worthwhile. This means $u_{2}^{c}(237 ; 379)=606=t\left(x_{2}=0\right)$ and $u_{1}^{c}(237 ; 379)=148<$ $u_{1}^{t}(237 ; 0)=157$, while the target value of PLAYER 1 is $u_{1}^{t}=v_{1}-x_{1}^{c}-u_{2}^{c}$ if the transfer is accepted. Thus, the societal gain from the transfer is $u_{1}^{t}-u_{1}^{c}=9$. 
The conflict investment $x_{2}^{c}=379$ can be avoided by the transfer. Shares in the prize towards the PLAYER with the lower valuation has a socially undesirable effect in the amount of $\left(v_{1}-v_{2}\right) p_{2}^{c}=-369$, depending on the share of the prize of PLAYER 2 in the Cournot equilibrium $p_{2}^{c}$.

(b) $\quad v_{1}=1000 ; v_{2}=1700$. The ratio is smaller than for indifference, so a transfer is not worthwhile. This means $u_{2}^{c}(233 ; 396)=674=t\left(x_{2}=0\right)$ and $u_{1}^{c}(233 ; 396)=137>$ $u_{1}^{t}(237 ; 0)=93$. Thus, the societal gain from the transfer is $u_{1}^{t}-u_{1}^{c}=-44$.

The saving of $x_{2}^{c}=396$ cannot outweigh the damage caused by the redistribution of the prize towards the PLAYER with lower valuation amounting to $\left(v_{1}-v_{2}\right) p_{2}^{c}=-441$. In an investigation of the pre-play stage, this would be an argument to let PLAYER 2 be the transfer payer.

(c) $v_{1}=1600 ; v_{2}=1000$. The ratio is significantly higher than with indifference, so a transfer is worthwhile. This means $u_{2}^{c}(379 ; 237)=148=t\left(x_{2}=0\right)$ and $u_{1}^{c}(379 ; 237)=$ $606<u_{1}^{t}(237 ; 0)=1073$. Thus, the societal effect of the transfer is $u_{1}^{t}-u_{1}^{c}=467$.

Both the saving of $x_{2}^{c}=237$ and the redistribution of the prize to the PLAYER with higher valuation to the amount of $\left(v_{1}-v_{2}\right) p_{2}^{c}=231$ put PLAYER 1 in a better position.

\section{b. Total peace}

Since $x_{1}$ only enters $u_{2}$ as an expectation in the case of a transfer payment, the only costs that arise for $x_{2}=0$ are due to the then unnecessary $x_{1}$. This makes the corner solution $x_{1} \rightarrow 0$ appear to be gainful in saving these costs. However, this is only profitable if it is possible not to meet PLAYER 2's expectations (i.e., if disappointment for PLAYER 2 is possible). If PLAYER 2 expects intended $x_{1}=\epsilon$, with $\epsilon$ as a very small number, the transfer amount $t\left(x_{2}=0\right)=u_{2}\left(\epsilon, x_{2}^{o}\right)=p_{2}\left(\epsilon, x_{2}^{o}\right) v_{2}-x_{2}^{o}$ must be much higher, since $p_{2}\left(\epsilon, x_{2}^{o}\right)=x_{2}^{o} /\left(\epsilon+x_{2}^{o}\right) \rightarrow 1$ [54] (p. 106). In addition, any other small conflict investment by PLAYER 2 immediately leads to a large share of the prize.

A numerical example illustrates this. Take example c) from above with $\epsilon=1$. Thus $x_{2}^{o}=x_{2}^{R}(1)=31$ and $u_{2}(1 ; 31)=938=t\left(x_{2}=0\right)>u_{2}^{c}(379 ; 237)=148$. While the advantage of redistributing the prize is even more powerful, since $p_{2}(1 ; 31)=0.969>$ $p_{2}^{c}(379 ; 237)=0.385$, the increase in the necessary transfer amount has a noticeable effect, as $u_{1}^{t}(1 ; 0)=661<u_{1}^{t}(237 ; 0)=1073$ illustrates.

\section{c. Marginal benefit calculus}

As shown, because of the truthful expectations, $x_{1}=\epsilon$ is a strategically poor choice. However, the question of optimal $x_{1}$ remains. How can costs associated with conflict investment be saved without having to increase the transfer amount too much?

PLAYER 1 can determine the optimal transfer amount by comparing the marginal benefits of the transfer for PLAYER 2 in the case of acceptance, with the amount of the marginal costs of further conflict investments for PLAYER 2; that is, the opportunity costs of accepting the transfer. Equating the two effects yields $x_{1}^{t^{*}}$ which maximizes the objective function of an optimal transfer $t^{*}$, which is expected to be accepted, indicated by the superscript index $*$.

$$
\begin{gathered}
\frac{\partial u_{2}\left(x_{2}=0\right)}{\partial t}=\left|\frac{\partial u_{2}\left(x_{2}>0\right)}{\partial x_{1}}\right|, \\
1=\left|-\frac{x_{2} v_{2}}{\left(x_{1}+x_{2}\right)^{2}}\right| .
\end{gathered}
$$

Rearranging results in

$$
x_{1}^{t^{*}}\left(x_{2}\right)=\sqrt{x_{2} v_{2}}-x_{2} .
$$

The marginal costs of transfer and conflict are assumed to be constant and equal for PLAYER 1, which is why they do not need to be considered further in the calculation. The marginal net gains of the two alternatives must be compared, with both sides reduced by the same cost. 


$$
\frac{\partial u_{1}\left(x_{2}=0\right)}{\partial t}=-1=\frac{\partial u_{1}}{\partial x_{1}} .
$$

This situation results in the following solution by substituting the reaction function of PLAYER 2, which equals the expectation of PLAYER 1 regarding PLAYER 2's expectation of PLAYER 1's action:

$$
x_{1}^{t^{*}}\left(x_{2}^{R}\right)=0,25 v_{2} .
$$

The reaction of PLAYER 2 given by formula (3) is also

$$
x_{2}^{R}\left(x_{1}^{t^{*}}\right)=0,25 v_{2} .
$$

For $x_{1}>x_{1}^{*}$, an increase in the attractiveness of the transfer option would be worthwhile to reduce $x_{1}$ further, while for $x_{1}<x_{1}^{*}$, an increase in $x_{1}$ can result in a worthwhile reduction in the transfer. The respective optimal transfer is

$$
t^{*}\left(x_{1}^{t^{*}}, x_{2}^{R}\right)=\left\{\begin{array}{cl}
u_{2}\left(x_{1}^{t^{*}}, x_{2}^{o}\right) & \text { for } x_{2}=0 \\
0 & \text { else }
\end{array}\right.
$$

or

$$
t^{*}\left(v_{2}\right)=\left\{\begin{array}{cl}
u_{2}\left(0,25 v_{2}, 0,25 v_{2}\right) & \text { for } x_{2}=0 \\
0 & \text { else. }
\end{array}\right.
$$

It is worth noting that $x_{1}^{t^{*}}$ does not depend on $v_{1}$. This is because by setting $x_{1}$ independent of $v_{1}$, it is not included in the calculus of PLAYER 2 (this circumstance could change if PLAYER 1 experiences liquidity problems). In general, this gives $x_{2}^{0}=0,25 v_{2}$, $t^{*}=u_{2}=0,25 v_{2}$ and $u_{1}^{t^{*}}=v_{1}-0,5 v_{2}$.

For the numerical example c), $x_{1}^{t^{*}}=250=x_{2}^{R}(250)$. It is $u_{2}(250 ; 250)=250=$ $t^{*}\left(x_{2}=0\right)$, and $u_{1}^{c}(379 ; 237)=606<u_{1}^{t}(237 ; 0)=1073<u_{1}^{t^{*}}(250 ; 0)=1100$. Thus, the social effect due to the optimal transfer is $u_{1}^{t^{*}}-u_{1}^{c}=494$. In addition to the saving of $x_{2}^{c}=237$ and the redistribution of the prize to the PLAYER with higher valuation (amounting to $\left(v_{1}-v_{2}\right) p_{2}^{c}=231$ ), the saving of $x_{i}^{c}-x_{1}^{t^{*}}=129$ is now added, reduced by the increase in the transfer $t^{*}\left(x_{2}=0\right)-t\left(x_{2}=0\right)=102$.

The deviation of $x_{1}^{t^{*}}$ to a higher (lower) value of $x_{1}=300$ (200), which would equally be anticipated by PLAYER 2, could only result in the target value $u_{1}^{t}=1095(1094)$. Remarkable is the accompanying change of $u_{2}^{t}=t=205$ (306), which, however, does not enter the calculation of PLAYER 1. Thus, the donor has a first mover advantage.

\section{Peace as a Public Good}

The problem has been studied as a conflict of two actors so far, the principal and the agent. To transfer it to the example of stopping free riding in the fight against climate change, it is necessary to illuminate the situation with several actors denoted by the set $M$. Let $1,2 \notin M$, with PLAYER 1 as the transfer payer, PLAYER 2 as the transfer recipient as above, and $h \in M$ as other members of society. Then, the CSF is

$$
p_{1}\left(x_{1}, x_{2}, \sum_{h} x_{h}\right)= \begin{cases}x_{1} /\left(x_{1}+x_{2}+\sum_{h} x_{h}\right) & \text { for }\left(x_{1}+x_{2}+\sum_{h} x_{h}\right)>0 \\ 1 /(2+|M|) & \text { else. }\end{cases}
$$

The marginal effect of a reduction of $x_{2}$ with positive conflict investments is then

$$
\frac{\partial p_{1}}{\partial x_{2}}=\left|-x_{1} /\left(x_{1}+x_{2}+\sum_{h} x_{h}\right)^{2}\right| .
$$


This positive effect also occurs for all $h$ as a positive externality of the transfer, since it is detached from the costs of the transfer. Thus, the reduction of conflict investment has the character of a public good, since PLAYERS $h$ are not excludable from a reduction of $x_{2}$, nor are they in rivalry for it. The classic problem of the underprovision of private provision of public goods due to free riding is to be expected, just as with altruistically motivated transfers [60].

Furthermore, $\partial p_{1} / \partial x_{2} \rightarrow 0$ for $\sum_{h} x_{h} \rightarrow \infty$, due to the concavity of $p_{1}$. Therefore, for large groups associated with a higher $\sum_{h} x_{h}$, the benefit of the transfer for PLAYER 2 is lower. This is offset by the lower transfer cost per reduction of $x_{2}$, since $p_{2}$ falls equally in $u_{2}^{c}$, the opportunity cost of accepting the transfer.

Finally, there is the consideration of pacifying all other PLAYERS with a transfer $t_{k}$. For this, let $1 \notin M$ and $2, k \in M$, where $h=k \backslash 2$ stands for all PLAYERS not being PLAYER 1 or 2 . Then, the sum of the transfers is

$$
\sum_{k} t_{k}=\sum_{2} u_{2}\left(x_{2}^{R}\left(x_{1}^{t}, \sum_{h} x_{h}^{t}=0\right), x_{1}^{t}, \sum_{h} x_{h}^{t}=0\right) .
$$

The individual transfers $t_{k}$, and therefore their sum, are higher in the case of multiple transfer recipients, since each one faces high marginal gains from its own conflict investments in comparison to the overall low level of conflict investments, differently from the case with a single transfer:

$$
\begin{aligned}
& \sum_{2} u_{2}\left[x_{2}^{R}\left(x_{1}^{t}, \sum_{h} x_{h}^{t}=0\right), x_{1}^{t}, \sum_{h} x_{h}^{t}=0\right] \\
& \quad>\sum_{2} u_{2}\left[x_{2}^{R}\left(x_{1}^{t}, \sum_{h} x_{h}^{R}\left(x_{1}^{t}, x_{2}^{R}\right)>0\right), x_{1}^{t}, \sum_{h} x_{h}^{R}\left(x_{1}^{t}, x_{2}^{R}\right)>0\right] .
\end{aligned}
$$

Therefore, a comprehensive transfer program by a single transfer provider is less profitable than it is for a smaller share of competitors. This is in line with the results of other research approaches [61]. When many competitors would like to pay a transfer to only one agent [62], the public good problem already presents itself in the precommitment stage.

In addition, the number of PLAYERS increases the problems of obtaining information for optimal transfer design and implementation. Nevertheless, in this study all PLAYERS are assumed to have equal conflict technology and that there are no liquidity restrictions in competition over the prize. However, nations are not equal. Larger nations may face a situation in which they are a larger contestant in comparison to others, and this may not be an advantage [63].

\section{Conclusions}

In the face of an imminent conflict equilibrium, it was shown that a credible transfer may avoid a destructive conflict. It is up to the transferor, PLAYER 1, to divide up the coveted prize, which she can do in her favor. In doing so, she must consider Player 2's expectations, as the transferee, of the outcome of the conflict, which is why caution is advised in dropping one's own conflict efforts. However, the optimal design of the transfer with unilateral adjustment of the expectations of a rational transferee allows some of the transferee's conflict investment to be lowered.

Paying fellow combatants for restraint is not a novel concept. Payment is akin to a cease-and-desist premium. The omission of the undesired activity, as in the example of conflict activity, is appreciated. For the recipient, the transfer must at least outweigh the opportunity costs to make it worthwhile to comply with the request to refrain. For those who request a change in behavior, the harm from the undesirable activity must at least outweigh the transfer necessary to persuade. 
Skaperdas and Syropoulos (1997) find that a relative improvement in conflict technology provides an advantage [64] (p. 108). This result can be applied to the size of the optimal transfer. In the provided model, equal conflict technology was assumed. Finally, the threat point of the conflict equilibrium always depends on the conflict technology, such that an improvement (deterioration) of the transfer recipient's conflict technology leads to a better (lower) threat point and thus to a higher (lower) transfer.

Furthermore, it should be pointed out once again that in this study, it was assumed that PLAYER 2 would accept the transfer to a certain extent in the case of the slightest betterment. This situation parallels the ultimatum game due to the clear differences in the payoffs to the benefit of PLAYER 1 depending on the acceptance of the transfer. The decision to accept the transfer and the conflict activity is thus clear for a homo economicus, but not for a human being or a government [65].

A credible transfer linked to conflict investment can at least unilaterally pacify a conflict situation. This finding provides scope for Pareto-efficient redistributive policies, as all parties benefit. The general nature of this research allows for multiple uses wherever a conflict is in trouble. Therefore, this concept could have the potential to foster commitment to an international cooperation. Whether such an agreement will be accomplished depends on incentives to play a war of attrition for the improvement of the relative position [11], i.e., gambling for receiving higher transfers, or paying lower compensations.

Accordingly, the design of a transfer for a climate agreement can solve some, but not all, of the problems of a global climate agreement. For example, a credible commitment in advance and a well-designed incentive scheme, also for individual country concerns [66], can mobilize the necessary efforts at the national level, which can contribute to a better success of the implementation [67]. Fraud and cheating on the treaties could be stopped by an enforcement authority with independent and respected oversight.

The recipient of the transfer would thus be linked to the achievement of the desired climate protection measures, for example $\mathrm{CO}_{2}$ savings, coal phase-out, and the establishment of nature reserves. The model suggests incentivizing through a transfer. For the case of international climate agreements, any international agent could start to declare their respective intention. For a large climate agreement and in order for such a transfer to be credibly offered, it is necessary to form and equip a corresponding organization for climate protection, such as the WTO for trade, which must be taken into account with the design of a global environmental governance $[68,69]$ and currently represents a functioning model for international cooperation [70]. The conference of the parties may be the appropriate institution for this task.

Furthermore, funds for missed targets could be retained and used elsewhere for the benefit of the climate target, e.g., for the purpose of compensation to incentivize beyond the agreed climate targets of individual countries. The New Green Deal [14,71] could serve as a model in its design. The integration of other instruments, such as a carbon tax, could also be applied [72].

On the other hand, specific issues of climate policy still require joint development efforts. Likewise, a leap of faith in the transfer provider and her success in effectively addressing climate change is necessary [73]. The details of effective and efficient incentives of the transfer design remain dependent on the respective literature on principal-agent problems.

This paper suggests conducting international agreements by setting up a transfer scheme based on a basic model. Thus, this approach may be extended by the plentiful aspects other strands of literature already incorporate. This includes changing the settings, for example to vary the turn sequence and thus the power in a Stackelberg game, broaching the issue of incomplete information and information asymmetry, or changing the contest success function. One may also endogenize the turn sequence by integrating the pre-play game or investigate an endogenous prize [63], since this allows for explicit modelling of the characteristics of a public good. Further, a repeated prisoner's dilemma converges into the chicken game, which tends to allow for easier cooperation and therefore Pareto improvements while bringing along the problem of reform delay $[74,75]$. 
On the application to climate agreements, the transfers as a tool in the form of grants is common at the national level. On an international scale, their application is usually not rule-bound but depends on application and approval, such as, for example, the European Regional Development Fund [76]. The necessary financial commitment in advance and trust in the institution to administer such a transfer program may be a hindrance. Nevertheless, a climate premium is discussed on the national level [46,50]. Similarly, the provided model could be tested in experiments on an individual level, as Abbink's survey on conflict experiments suggests [77].

Author Contributions: Conceptualization, M.F. and B.K.J.N.; formal analysis, M.F.; investigation, M.F.; writing — original draft preparation, M.F.; writing—review and editing, M.F. and B.K.J.N.; visualization, M.F. All authors have read and agreed to the published version of the manuscript.

Funding: This research received no external funding.

Institutional Review Board Statement: Not applicable.

Informed Consent Statement: Not applicable.

Data Availability Statement: Not applicable.

Acknowledgments: Thanks to Bianca Blum, Clem Davies, and Tobias Jäger for helpful discussions on the concept.

Conflicts of Interest: The authors declare no conflict of interest.

\section{Abbreviations}

1 Index for PLAYER 1, which is the transfer payer

2 Index for PLAYER 2, which is a transfer recipient

$\epsilon \quad$ A very small number

* Superscript index for the transfer that maximizes the objective function

$c \quad$ Superscript index for Cournot equilibrium

CSF Contest success function

$h \quad$ Other members of society than PLAYER 1 and PLAYER 2

$i \quad$ Index for the PLAYERs, $i \in\{1,2\}$

$j \quad$ Index for the respective competitor, i.e., the other PLAYER

$k \quad$ Other members of society than PLAYER 1

$M \quad$ Set of several actors in a society

$o \quad$ Superscript index for action rejecting the transfer

$p_{i} \quad$ Probability of winning, mathematical representation of the contest success function (CSF)

$p_{2}^{c} \quad$ Probability of winning of PLAYER 2 in the Cournot equilibrium

$R$ Superscript index for reaction function $t$ Transfer program, also may be used as superscript index for actions in accordance with the incentives by the transfer scheme

$t^{*} \quad$ Optimal transfer program

$t_{k} \quad$ Transfer program targeting all other PLAYERs

$u_{i} \quad$ Target function, also known as objective function

$u_{1}^{t} \quad$ Target value for PLAYER 1 if the transfer is accepted by PLAYER 2

$u_{i}^{c} \quad$ Target function of the Cournot equilibrium

$v_{i} \quad$ Valuation of the total potential prize

$x_{i} \quad$ Conflict efforts

$x_{i}^{c} \quad$ Conflict efforts in the Cournot equilibrium

$x_{i}^{R} \quad$ Reaction function

$x_{1}^{t^{*}} \quad$ Conflict effort of PLAYER 1 that maximizes the utility of an expectedly accepted transfer

$x_{2}^{0} \quad$ Conflict efforts by PLAYER 2 if the transfer is rejected

$x_{2}^{t} \quad$ Conflict efforts by PLAYER 2 if the transfer is accepted 


\section{References}

1. Nordhaus, W. Climate Change: The Ultimate Challenge for Economics. Am. Econ. Rev. 2019, 109, 1991-2014. [CrossRef]

2. Kaul, I. Global Public Goods: Explaining their Underprovision. J. Int. Econ. Law 2012, 15, 729-750. [CrossRef]

3. Eyckmans, J.; Finus, M. Measures to enhance the success of global climate treaties. Int. Environ. Agreem. Politics Law Econ. 2007, 7, 73-97. [CrossRef]

4. Falkner, R. A Minilateral Solution for Global Climate Change? On Bargaining Efficiency, Club Benefits, and International Legitimacy. Perspect. Politics 2016, 14, 87-101. [CrossRef]

5. Costantini, V.; Sforna, G.; Zoli, M. Interpreting bargaining strategies of developing countries in climate negotiations. A quantitative approach. Ecol. Econ. 2016, 121, 128-139. [CrossRef]

6. Najam, A. Climate negotiations beyond Kyoto: Developing countries concerns and interests. Clim. Policy 2003, 3, $221-231$. [CrossRef]

7. Betsill, M.M.; Bulkeley, H. Cities and the Multilevel Governance of Global Climate Change. Glob. Gov. 2006, 12, 141-159. [CrossRef]

8. Newell, P. The political economy of global environmental governance. Rev. Int. Stud. 2008, 34, 507-529. [CrossRef]

9. Sand, P.H. Lessons learned in global environmental governance. Boston Coll. Environ. Aff. Law Rev. 1990, 18, 213.

10. Bernstein, S. Legitimacy in global environmental governance. J. Int. Law Int. Relat. 2004, 1, 139-166.

11. Kontodaimon, M.; Neumärker, B. Two Level Reform Game Problems of Greece; Chapter 4; The Constitutional Economics Network Working Papers 03-2015; University of Freiburg: Freiburg, Germany, 2016; pp. 67-84. [CrossRef]

12. Blankart, C.B. Öffentliche Finanzen in der Demokratie; Verlag Franz Vahlen GmbH: Berlin, Germany, 2017. [CrossRef]

13. Dixit, A. Strategic Behavior in Contests. Am. Econ. Rev. 1987, 77, 891-898.

14. Bergman, M.M. The World after COVID. World 2020, 1, 45-48. [CrossRef]

15. Blum, B.; Neumärker, B. Lessons from Globalization and the COVID-19 Pandemic for Economic, Environmental and Social Policy. World 2021, 2, 308-333. [CrossRef]

16. Barrett, S.; Stavins, R. Increasing Participation and Compliance in International Climate Change Agreements. Int. Environ. Agreem. Politics Law Econ. 2003, 3, 349-376. [CrossRef]

17. Abrahamson, E.; Park, C. Concealment of Negative Organizational Outcomes: An Agency Theory Perspective. Acad. Manag. J. 1994, 37, 1302-1334. [CrossRef]

18. De Freitas Netto, S.V.; Sobral, M.F.F.; Ribeiro, A.R.B.; da Luz Soares, G.R. Concepts and forms of green-washing: A systematic review. Environ. Sci. Eur. 2020, 32, 1. [CrossRef]

19. Helm, D. Government failure, rent-seeking, and capture: The design of climate change policy. Oxf. Rev. Econ. Policy 2010, 26, 182-196. [CrossRef]

20. Helm, C.; Wirl, F. The principal-agent model with multilateral externalities: An application to climate agreements. J. Environ. Econ. Manag. 2014, 67, 141-154. [CrossRef]

21. Nitzan, S. Modelling rent-seeking contests. Eur. J. Politics Econ. 1994, 10, 41-60. [CrossRef]

22. Kimbrough, E.O.; Laughren, K.; Sheremeta, R. War and conflict in economics: Theories, applications, and recent trends. J. Econ. Behav. Organ. 2020, 178, 998-1013. [CrossRef]

23. Anderton, C.H.; Carter, J.R. Chapter 35: A Survey of Peace Economics. In Handbook of Defense Economics; Elsevier: Amsterdam, The Netherlands, 2007; pp. 1211-1258. [CrossRef]

24. Wood, P.J. Climate change and game theory. Ann. N. Y. Acad. Sci. 2011, 1219, 153-170. [CrossRef] [PubMed]

25. Heitzig, J.; Lessmann, K.; Zou, Y. Self-enforcing strategies to deter free-riding in the climate change mitigation game and other repeated public good games. Proc. Natl. Acad. Sci. USA 2011, 108, 15739-15744. [CrossRef] [PubMed]

26. Kroll, S.; Shogren, J.F. Domestic politics and climate change: International public goods in two-level games. Camb. Rev. Int. Aff. 2008, 21, 563-583. [CrossRef]

27. Weiler, F. Determinants of bargaining success in the climate change negotiations. Clim. Policy 2012, 12, 552-574. [CrossRef]

28. Ciano, T.; Ferrara, M.; Gangemi, M.; Merenda, D.; Pansera, B. Climate Change Sustainability: From Bargaining to Cooperative Balanced Approach. Games 2021, 12, 45. [CrossRef]

29. Brandts, J.; Saijo, T.; Schram, A. How Universal is Behavior? A Four Country Comparison of Spite and Cooperation in Voluntary Contribution Mechanisms. Public Choice 2004, 119, 381-424. [CrossRef]

30. Goeschl, T.; Kettner, S.E.; Lohse, J.; Schwieren, C. How much can we learn about voluntary climate action from behavior in public goods games? Ecol. Econ. 2020, 171, 106591. [CrossRef]

31. Thompson, A. Management Under Anarchy: The International Politics of Climate Change. Clim. Chang. 2006, 78, 7-29. [CrossRef]

32. Caparrós, A. Bargaining and International Environmental Agreements. Environ. Resour. Econ. 2016, 65, 5-31. [CrossRef]

33. Barrett, S. Self-Enforcing International Environmental Agreements. Oxf. Econ. Pap. 1994, 46, 878-894. [CrossRef]

34. Lessmann, K.; Kornek, U.; Bosetti, V.; Dellink, R.; Emmerling, J.; Eyckmans, J.; Nagashima, M.; Weikard, H.-P.; Yang, Z. The Stability and Effectiveness of Climate Coalitions. Environ. Resour. Econ. 2015, 62, 811-836. [CrossRef]

35. Bagwell, K.; Staiger, R.W. Enforcement, Private Political Pressure, and the General Agreement on Tariffs and Trade/World Trade Organization Escape Clause. J. Leg. Stud. 2005, 34, 471-513. [CrossRef] 
36. Kappius, R.; Neumärker, B. Second chapter Could Exit Rules be Self-Enforcing in the EU? The Cases of France and Germany. Eur. Crisis Nomos. 2016, 2016, 35-46. [CrossRef]

37. Martimort, D.; Sand-Zantman, W. A Mechanism Design Approach to Climate-Change Agreements. J. Eur. Econ. Assoc. 2016, 14, 669-718. [CrossRef]

38. Varian, H.R. Monitoring Agents with Other Agents. J. Inst. Theor. Econ. 1990, 146, 153-174.

39. Hart, O.; Holmström, B. The theory of contracts. In Advances in Economic Theory; Cambridge University Press: Cambridge, UK, 1987; pp. 71-156. [CrossRef]

40. White, B.; Hanley, N. Should We Pay for Ecosystem Service Outputs, Inputs or Both? Environ. Resour. Econ. 2016, 63, 765-787. [CrossRef]

41. Derissen, S.; Quaas, M. Combining performance-based and action-based payments to provide environmental goods under uncertainty. Ecol. Econ. 2013, 85, 77-84. [CrossRef]

42. Hochman, H.H.; Rodgers, J.D. Pareto Optimal Redistribution. Am. Econ. Rev. 1969, 59, 542-557.

43. Brennan, G. Pareto desirable redistribution: The non-altruistic dimension. Public Choice 1973, 14, 43-67. [CrossRef]

44. Brennan, G. Pareto desirable redistribution: The case of malice and envy. J. Public Econ. 1973, 2, 173-183. [CrossRef]

45. Brennan, G. Pareto-Optimal Redistribution: A Perspective. Public Financ. Anal. 1975, 33, 237-271.

46. Buchanan, J.M. The relevance of Pareto optimality. J. Confl. Resolut. 1962, 6, 341-354. [CrossRef]

47. Wyss, R. The Tolerance Premium as a Constitutional Element of the Protective Welfare State; Constitutional Economic Network Papers; University of Freiburg: Freiburg, Germany, 2011.

48. Buchanan, J.M. The Limits of Liberty: Between Anarchy and Leviathan; Library of Economics and Liberty: London, UK, 1999; Volume 7.

49. Lehto, O.; Meadowcroft, J. Welfare without rent seeking? Buchanan's demogrant proposal and the possibility of a constitutional welfare state. Const. Political Econ. 2020, 32, 145-164. [CrossRef]

50. Gründinger, W.; Bendling, L.; Creutzig, F.; Hagedorn, G.; Kemfert, C.; Neumärker, B.; Praetorius, B.; Tvrtković, M. CO ${ }_{2}-$ Bepreisung und soziale Ungleichheit in Deutschland. CO2-Bepreisung und soziale Ungleichheit in Deutschland. Momentum Q. -Z. Soz. Fortschr. 2021, 10, 176. [CrossRef]

51. Wärneryd, K. Informational Aspects of Conflict; Oxford University Press: Oxford, UK, 2012. [CrossRef]

52. Cuesta, J.; Murshed, S.M. On the Micro-Foundations of Contract Versus Conflict with Implications for International Peace-Making. SSRN Electron. J. 2008, 2, 34726746. [CrossRef]

53. Skaperdas, S. Contest Success Functions. Econ. Theory 1996, 7, 283-290. [CrossRef]

54. Hirshleifer, J. Conflict and rent-seeking success functions: Ratio vs. difference models of relative success. Public Choice 1989, 63, 101-112. [CrossRef]

55. Bracht, J.; Feltovich, N. Efficiency in the trust game: An experimental study of precommitment. Int. J. Game Theory 2007, 37, 39-72. [CrossRef]

56. Harsanyi, J.C. Bargaining in ignorance of the opponent's utility function. J. Confl. Resolut. 1962, 6, 29-38. [CrossRef]

57. Neumärker, K.J.B. Ordnungspolitik, Neuer Ordoliberalismus und Mainstream Economics. WISU 2017, 46, 830-840.

58. European Commission. Effort Sharing: Member States' Emission Targets. Available online: https://ec.europa.eu/clima/euaction/effort-sharing-member-states-emission-targets_en (accessed on 17 January 2022).

59. Hirshleifer, J. The Analytics of Continuing Conflict. Synthese 1988, 76, 201-233. [CrossRef]

60. Musgrave, R.A. Pareto Optimal Redistribution: Comment. Am. Econ. Rev. 1970, 60, 991-993.

61. Smead, R.; Sandler, R.L.; Forber, P.; Basl, J. A bargaining game analysis of international climate negotiations. Nat. Clim. Chang. 2014, 4, 442-445. [CrossRef]

62. Neumärker, K.J.B. Finanzverfassung und Staatsgewalt in der Demokratie; Peter Lang GmbH: Frankfurt am Main, Germany, 1995; Volume 67.

63. Hirshleifer, J. The Paradox of Power. Econ. Politics 1991, 3, 177-200. [CrossRef]

64. Skaperdas, S.; Syropoulos, C. The Distribution of Income in the Presence of Appropriative Activities. Economica 1997, 64, 101-1117. [CrossRef]

65. Güth, W.; Kocher, M. More than thirty years of ultimatum bargaining experiments: Motives, variations, and a survey of the recent literature. J. Econ. Behav. Organ. 2014, 108, 396-409. [CrossRef]

66. Moriarty, P.; Honnery, D. New Approaches for Ecological and Social Sustainability in a Post-Pandemic World. World 2020, 1, 191-204. [CrossRef]

67. Kish, K.; Zywert, K.; Hensher, M.; Davy, B.J.; Quilley, S. Socioecological System Transformation: Lessons from COVID-19. World 2021, 2, 15-31. [CrossRef]

68. Green, A. Climate Change, Regulatory Policy and the WTO. J. Int. Econ. Law 2005, 8, 143-189. [CrossRef]

69. O'Neill, K.; Weinthal, E.; Suiseeya, K.R.M.; Bernstein, S.; Cohn, A.; Stone, M.W.; Cashore, B. Methods and Global Environmental Governance. Annu. Rev. Environ. Resour. 2013, 38, 441-471. [CrossRef]

70. Zhao, L.; Karaivanova, A.; Zhang, P. The Complementary Role of the WTO in the Enhancement of the Base Erosion and Profit Shifting Project. World 2021, 2, 267-294. [CrossRef]

71. Hough, D.; White, E. The Green Deal; Library House of Commons: London, UK, 2014. 
72. Condon, B.J. Climate Change and Unresolved Issues in WTO Law. J. Int. Econ. Law 2009, 12, 895-926. [CrossRef]

73. Sell, S. North-South Environmental Bargaining: Ozone, Climate Change, and Biodiversity. Glob. Gov. 1996, 2, 97-118. [CrossRef]

74. Sandler, T. Collective Action; University of Michigan Press: Ann Arbor, MI, USA, 1992.

75. Drazen, A. The political economy of delayed reform. J. Policy Reform. 1996, 1, 25-46. [CrossRef]

76. European Commission. European Regional Development Fund. Available online: https://ec.europa.eu/regional_policy/en/ funding/erdf/ (accessed on 17 January 2022).

77. Abbink, K. Laboratory Experiments on Conflict; Grafinkel, M.R., Skaperdas, S., Eds.; Oxford University Press: Oxford, UK, 2012; pp. 532-553. 